\title{
A Postmortem Study on the Weight of the Human Ovary
}

Perven $\mathrm{HA}^{1}$, Nurunnabi $\mathrm{ASM}^{2}$, Ara $\mathrm{S}^{3}$, Shahriah $\mathrm{S}^{4}$, Begum $\mathrm{GN}^{5}$

\begin{abstract}
A cross-sectional, descriptive type of study was designed to find out the difference in weight of the ovary of Bangladeshi women in relation to age and to compare with the previous studies. This study was done in the Department of Anatomy, Dhaka Medical College, Dhaka, from January to December 2009. The study was performed on 140 post mortem human ovaries collected from 70 unclaimed female dead bodies which were in the morgue under examination in the Department of Forensic Medicine, Dhaka Medical College, Dhaka. The samples were divided into three age-groups including group A (10-13 years), group B (14-45 years) \& group $C$ (46-52 years) and the weight of the ovaries were measured and recorded. The difference in mean weight between the right ovary and the left ovary was statistically significant in all age group $(P<0.001)$. The difference in mean weight of the ovary between group $A \&$ group $B$, group $A \&$ group $C$ and group $B$ $\&$ group $C$ were statistically significant $(P<0.001)$.
\end{abstract}

\section{Key words}

Human ovary, weight of ovary.

\section{Introduction}

The ovaries are the primary female reproductive organs and endocrine glands, which are situated in the lesser pelvis on each side of the uterus and are attached to the posterior layer of the broad ligament below and behind corresponding uterine tube $^{1}$. The ovary has important gametogenic functions that are integrated with its hormonal activity ${ }^{2}$. Ovarian pathology can manifest in various ways e.g. menstrual abnormality, cystic disease, infertility, benign or malignant tumours etc. Exact knowledge of the normal morphometry e.g. the weight of the ovary, may facilitate the gynaecologists, endocrinologists, pathologists and radiologists to adopt appropriate diagnosis and treatment of various clinical conditions associated of the ovaries $^{3}$. Ovarian weight may be affected by patients' age, laterality of the organ and presence of systemic disease ${ }^{4}$.

1. Corresponding Author: Dr. Hosna Ara Perven Assistant Professor, Department of Anatomy The Medical College for Women \& Hospital, Uttara, Dhaka.

2. Dr. Abu Sadat Mohammad Nurunnabi Lecturer, Department of Anatomy Dhaka Medical College, Dhaka.

3. Prof. Shamim Ara Professor \& Head, Department of Anatomy Dhaka Medical College, Dhaka.

4. Dr. Sunjida Shahriah Associate Professor, Department of Anatomy ZH Sikder Women's Medical College, Dhaka.

5. Dr. Gul Newaz Begum Associate Professor, Department of Anatomy Anwar Khan Modern Medical College, Dhaka.
Moreover, it has been observed by various researchers that the dimensions of different organs in Bangladeshi population have got variations from those of the western population ${ }^{5}$. It is also observed by reviewing the literature and the texts that several works have been done on the ovary in foreign countries but proper attention has not been given to the normal morphological study in our country ${ }^{6}$. Therefore, the study of the weight of this important organ has been designed to see whether there is any variation with age in Bangladeshi women as well as with those of the western studies.

\section{Materials and Methods}

A cross-sectional descriptive type of study was designed and done in the Department of Anatomy, Dhaka Medical College, Dhaka, from January to December 2009, based on collection of 140 human ovaries from 70 unclaimed female dead bodies (age range 12-52 years) that were under examination in the Department of Forensic Medicine, Dhaka Medical College, Dhaka, from May to October 2009. All the samples were collected within 24-36 hours of death without any sign of putrefaction. All the samples were collected from medicolegal cases excluding poisoning, any cutting or crushing injury to the ovary, ovary found in one side and diseased ovaries. This study was approved by the Ethical Review Committee of Dhaka Medical College, Dhaka.

After isolation, the samples were divided into three agegroups i.e. Group A (10-13 years), Group B (14-45 years) \& Group C (46-52 years) (Table-I), according to Kumar and Malhotra $^{7}$. Here, group A is pre-menarche group, group B represents reproductive age and group $\mathrm{C}$ is post menopausal group.

Table-I: Grouping of the sample of the present study $(n=140)$

\begin{tabular}{cccc}
\hline Group & Age limit in years & \multicolumn{2}{c}{ Number of samples } \\
& & Right & Left \\
\hline A & $10-13$ & 7 & 7 \\
B & $14-45$ & 50 & 50 \\
C & $46-52$ & 13 & 13 \\
\hline
\end{tabular}

Measurement of weight of the ovary: The ovary was taken and its outer surface was dried with blotting paper. Then it was weighed by means of a digital balance (SCIENTECH ZSA 210, made in USA) in grams.

Statistical processing of data: The comparison between right and left side was done by unpaired Student's ' $t$ ' test and the comparison between different groups was done by One-way ANOVA. All the statistical analyses were done by using the SPSS 13.0 version.

\section{Results}

The difference in mean weight between the right ovary and 
the left ovary was statistically significant in all age group i.e. the right ovary is greater in weight than that of the left (Table-II, Fig.1). The difference in mean weight of the ovary between group A \& group B, group A \& group C and group B \& group $\mathrm{C}$ were statistically significant (Table-II, Fig.1).

Table-II: Weight of right and left ovary in different age group

\begin{tabular}{cccc}
\hline \multirow{2}{*}{$\begin{array}{c}\text { Wge } \\
\text { group }\end{array}$} & $\begin{array}{c}\text { Right } \\
\text { (mean } \pm \text { SD) }\end{array}$ & $\begin{array}{c}\text { Left } \\
\text { (mean } \pm \text { SD) }\end{array}$ & P value \\
\hline A & $3.13 \pm 0.06$ & $2.83 \pm 0.10$ & $<0.001 * * *$ \\
$(\mathrm{n}=7)$ & $(3.05-3.21)$ & $(2.70-3.00)$ & \\
$\mathrm{B}$ & $5.17 \pm 0.85$ & $4.54 \pm 0.75$ & $<0.001 * * *$ \\
$(\mathrm{n}=50)$ & $(3.67-6.65)$ & $(3.10-6.80)$ & \\
$\mathrm{C}$ & $1.06 \pm 0.16$ & $0.81 \pm 0.15$ & $<0.001 * * *$ \\
$(\mathrm{n}=13)$ & $(0.85-1.30)$ & $(0.60-0.98)$ & \\
& $\mathrm{P}$ value & $\mathrm{P}$ value & \\
A vs $\mathrm{B}$ & $<0.001 * * *$ & $<0.001 * * *$ & \\
A vs C & $<0.001 * * *$ & $<0.001 * * *$ & \\
$\mathrm{~B}$ vs C & $<0.001 * * *$ & $<0.001 * * *$ & \\
\hline
\end{tabular}

Figures in parentheses indicate range. Comparison between the right $\&$ the left side done by unpaired Student's ' $t$ ' test and in between different age group were done by One-way ANOVA $($ PostHoc $), \mathrm{ns}=$ not significant, $* * / * * *=$ significant.

Group A: 10-13 years

Group B: $14-45$ years

Group C: $46-52$ years

Fig. 1. Weight of right and left ovaries in different age group

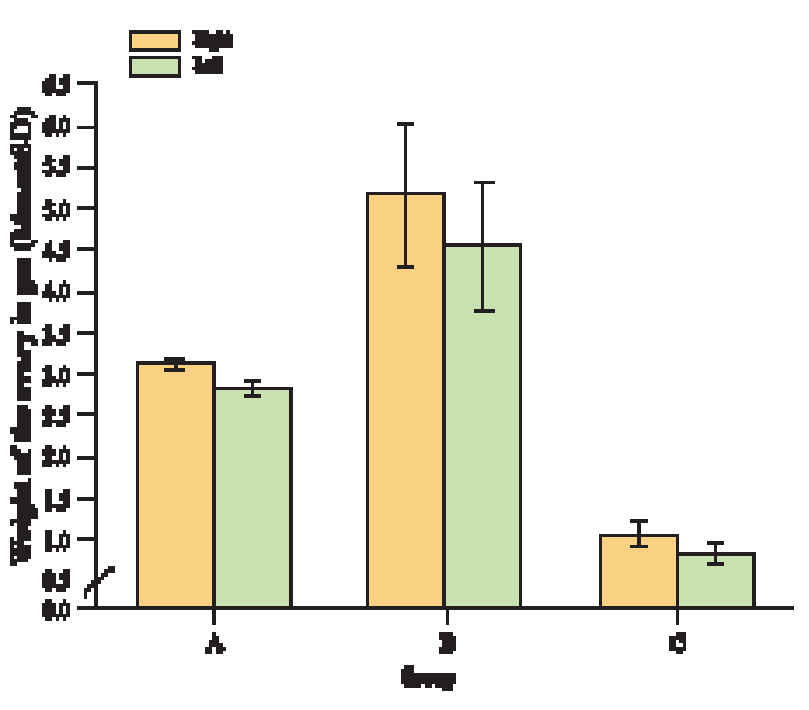

\section{Discussion}

Damjanov and Linder ${ }^{8}$ stated the weight of the ovary is 5-8 gm. Romanes ${ }^{9}$ stated that the ovarian weight is in between 5-10 gm. According to Thibodeau and Patton ${ }^{10}$, the weight of the ovary is $3 \mathrm{gm}$. Bhatla ${ }^{4}$ stated that the overies are 4-8 gm and the right tends to be larger than the left. Kumar and Malhotra $^{7}$, Rosai ${ }^{11}$, Krantz ${ }^{12}$ stated that the weight of the ovary is 4-8 gm. According to Kumar et al. ${ }^{3}$, the weight of the normal ovary is 4 grams. Narongchai duo ${ }^{13}$ performed autopsy of Thai corpses aged between 15 and 60 years and stated that the weight of the right ovaries were 6.7-9.6 gm and the left ovaries 5.5-9.8 gm. Ahmed et al. ${ }^{6}$ studied 62 pair of ovaries and found the mean weight of the right ovary and left ovary $3.36 \pm 0.50 \mathrm{gm}$ and $2.72 \pm 0.52 \mathrm{gm}$ in group A (2-13 years), $4.93 \pm 1.94 \mathrm{gm}$ and $5.01 \pm 1.51 \mathrm{gm}$ in group B (14-45 years) and $5.78 \pm 1.07 \mathrm{gm}$ and $4.71 \pm 0.76 \mathrm{gm}$ in group $\mathrm{C}$ (4680 years) respectively in Bangladeshi cadavers. The present study reveals the fact that the mean weight of the right ovary was $3.13 \pm 0.06$ gm in group A (10-13 years), $5.17 \pm 0.85 \mathrm{gm}$ in group B (14-45 years) and 1.06 \pm 0.06 gm in group C (46-52 years). The mean $\pm \mathrm{SD}$ weight of the left ovary was $2.83 \pm 0.10$ gm, $4.54 \pm 0.75 \mathrm{gm}$ and $0.81 \pm 0.14 \mathrm{gm}$ in group A, B and C respectively. The highest mean weight was found in group $\mathrm{B}$ and the lowest was in group $\mathrm{C}$ in both the ovaries. The above mentioned result is similar to that of Damjanov and Linder $^{8}$, Romanes ${ }^{9}$, Bhatla ${ }^{4}$, Rosai ${ }^{11}$, Krantz $^{12}$ and Ahmed et al. ${ }^{6}$. However, the findings of Thibodeau and Patton ${ }^{10}$ are lower, while the findings of Narongchai duo ${ }^{13}$ are higher than that of the present study, which may be due to racial variation and difference in measuring instruments.

Further studies with larger sample and high technical backup are recommended. The results of the present study can be used as a standard reference weight for the ovaries of Bangladeshi women and to determine the abnormal evidences in forensic and pathologic corpses.

\section{Acknowledegement}

We would like to express our deepest gratitude to the authority of Health, Nutrition \& Population Sector Programme (HNPSP) of Directorate General of Health Services (DGHS) of the Government of the People's Republic of Bangladesh and Dhaka Medical College, Dhaka, for the research grant.

\section{References}

1. Healy JC. Female reproductive system. In: Stranding S, Borley NR, Collins P, Crossman AR, Gatzoulis MA, Healy JC, et al. eds. Gray's anatomy: the anatomical basis of clinical practice. $40^{\text {th }}$ ed. Edinburgh: Elsevier Churchill Livingstone; 2008: p.1293-9.

2. Guyton AC and Hall JE. Female physiology before pregnancy and female hormones. In: Textbook of medical physiology. $11^{\text {th }}$ ed. New Delhi: Elsevier; 2006: p.869-83.

3. Kumar V, Abbas AK, Fausto N, Aster JC. eds. Robbins and Cotran pathologic basis of disease. $8^{\text {th }}$ ed. New Delhi: Elsevier Saunders; 2010: p.1007. 
4. Bhatla N. Principles of gynaecology. $5^{\text {th }}$ ed. New Delhi: Arnold; 2001: p.38.

5. Enayetullah M. Gross and histomorphological study of the thyroid and parathyroid glands in Bangladeshi people (M.Phil.Thesis). Dhaka: IPGMR, University of Dhaka; 1996. p.17.

6. Ahmed MS, Rahman H, Ara ZG, Sultana SZ, Rahman M. Morphological study of weight of the ovary at different age group in Bangladeshi people. Bangladesh J Med Science 2011; 10(4): 266-8.

7. Kumar P, Malhotra N. eds. Jeffcoate's principles of gynaecology. $7^{\text {th }}$ ed. New Delhi: Jaypee; 2008: p.36.

8. Damjanov I, Linder J. Female reproductive system. In: eds. Anderson's pathology. $10^{\text {th }}$ ed. St. Louis: Mosby; 1996: p.2278-95.

9. Romanes GJ. ed. Cunningham's manual of practical anatomy. Vol. 2. (Thorax and abdomen). $15^{\text {th }} \mathrm{ed}$. New
York: Oxford University Press; 2000: p.211-3.

10. Thibodeau GA, Patton KT. eds. Anatomy and physiology. $5^{\text {th }}$ ed. St. Louis: Mosby; 2003: p.914-6.

11. Rosai J. Rosai and Ackerman's Surgical Pathology. Vol. 2. $9^{\text {th }}$ ed. New Delhi: Thomson Press; 2005: p.16491709.

12. Krantz KE. Anatomy of the female reproductive system. In: DeCherney AH, Goodwin TM, Nathan L, Laufer N. eds. Current diagnosis \& treatment - Obstetrics \& Gynecology. 10 ${ }^{\text {th }}$ ed. New York: McGraw-Hill; 2007: p.47-8.

13. Narongchai P, Narongchai S. Study of the normal internal organ weights in Thai population. J Med Assoc Thai 2008; 91(5): 747-53. 